\title{
Is Russia an Arctic Status Quo Power?
}

Morten Larsen Nonboe phd-studerende, Institut for Statskundskab, Aarhus Universitet, email: MLN@ps.au.dk.

Russian foreign policy in the increasingly important Arctic region reflects an ambiguous combination of assertiveness and cooperation in accordance with international law. Against this background, the existing literature on the Arctic tends to polarise around revisionist and status quo interpretations of Russian foreign policy in the region. Based on case studies this article provides support for a modified version of the status quo interpretation which incorporates insights from the revisionist interpretation.

\section{Russia and the Arctic}

The existing literature on Russian foreign policy in the Arctic is divided into two competing camps. One approach emphasises assertive Russian actions like the Russian flag planting on the seabed beneath the North Pole in 2007 and downplays Russia's adherence to the legal framework in the Arctic region whose economic potential is increasingly highlighted by the effects of global warming (Borgerson 2008: 65-74, Petersen 2008: 47, Baev 2010: 25-26). Ominously, it has been suggested that Russia is merely 'paying lip service to international law' and appears to believe that 'credible displays of power will settle conflicting territorial claims' in the Arctic (Cohen, Szaszdi \& Dolbow 2008: 1). Russia's actions in the Arctic have in fact even been linked to a looming 'New Cold War' between Russia and the West (Lucas 2009: 186-187).

Another approach, by contrast, is inclined to dismiss assertive Russian actions like the flag planting or the resumption of Soviet-era strategic bomber flight patrols over the Arctic Ocean and underlines Russia's adherence to the existing legal framework in the Arctic (Rowe 2009:
10, Zyśk 2009: 106, Trenin 2010: 10-12, Indzhiyev 2010: 117-118). Specifically, the approach stresses that Russia bases its claims in the ice-covered Arctic Ocean on the UN Convention on the Law of the Sea (UNCLOS) ${ }^{1}$ and has abrogated the Soviet sector principle according to which the Soviet Union unilaterally claimed a triangular sector between the Soviet Union's North-eastern and North-western borders and the North Pole in 1926 (Indzhiyev 2010: 16-20, Kazmin 2010: 15). The approach also highlights Russia's participation in the 'Arctic Five' cooperation with the other Arctic coastal states (Canada, Denmark, Norway, and the United States). The 'Arctic Five' cooperation is based on the UNCLOS and was formally launched at the Ilulissat Summit in May 2008 when the 'Arctic Five' signed the Ilulissat Declaration and committed themselves to an 'orderly settlement of any possible overlapping claims' based on the existing legal framework in the Arctic (Ilulissat Declaration 2008). For these reasons, a Russian observer has posited that Russia's Arctic policy aims to maintain 'the status quo in the Arctic waters which exists from the Soviet period' until Russia achieves UN recognition of its claims (Golotiuk 2008: 3).

The divergent interpretations make it relevant to study Russian foreign policy in the Arctic in further detail. Drawing on the distinction between the ideal types of revisionist and status quo powers in international relations, the existing literature can be synthesised into revisionist and status quo interpretations. The realist premise underlying the distinction between revisionist and status quo powers suggests that all policies seek to either increase or keep power. Accordingly, a state whose foreign policy aims at acquiring more power conducts a revisionist foreign policy, while a state whose foreign policy aims at maintaining the distribution of power pursues a policy 
of the status quo (Morgenthau 1973: 40-41). In operationalisable terms, a state's attitude towards the rules of an international system distinguishes revisionist from status quo powers. From this perspective, a revisionist power is discernable from a status quo power by its compliance with the existing international institutions and the framework of international law (Gilpin 1981: 34-36, Johnston 2003: 8-12). Given the importance of the UNCLOS in an Arctic context, adherence to the UNCLOS therefore constitutes an important indicator of whether Russia is best classified as a revisionist power challenging the provisions of the UNCLOS or a status quo power adhering to the existing legal framework.

The present paper aims to test the competing interpretations through case studies of the Russian flag planting in 2007 and the Ilulissat Summit in 2008 which can be treated as 'crucial cases' given their centrality to the competing interpretations (Eckstein 1975: 113-123, Gerring 2007: 115-122). The possibility of testing hypotheses using single case studies is disputed for various reasons and case studies entail obvious limitations with respect to external validity (King, Verba \& Keohane 1994: 209-211, George, Bennett 2005: 220-222). The 'crucial' case studies can, however, be seen as a 'plausibility probes' which attempt to determine whether the potential validity of the competing interpretations may reasonably be considered great enough to warrant further inquiry (Eckstein 1975: 108-109). The case studies, accordingly, seek to explore the validity of the two competing perspectives on Russian foreign policy in the Arctic and do not attempt to give a full account of Russia's Arctic policy which is beyond the scope of the paper. Conducting the case studies, the paper primarily relies on official statements from the Russian government and news coverage of the selected cases.

\section{The Russian Flag Planting on the North Pole Seabed}

In the summer of 2007, Russia performed the first ever manned descent to the seabed beneath the North Pole. The descent took place as a part of the expedition Arktika 2007 which was conducted by the Russian research vessel Akademik Fyodorov with the help of the icebreaker Rossiya. On 2 August 2007, the deep-submergence vehicles MIR-1 and MIR-2 submerged from the Akademik Fyodorov in the morning and reached the North Pole seabed around noon. MIR-1 and MIR-2 collected a number of specimens from the seabed, but most famously the MIR-1 also placed a large Russian titanium flag on the North Pole seabed (McDowell, Batson 2007: 11-13). After the descent, the leader of the expedition, the presidential advisor Artur Chilingarov, forcefully commented that 'there is the law of the sea and there is the right ${ }^{2}$ of "the first night" (...) the North Pole belongs to Russia' (Moskovskiy komsomolets 2007). The flag planting consequently sparked sharp reactions from the other Arctic coastal states. For instance, then Canadian foreign minister Peter MacKay was quoted saying that 'this isn't the 15 th century (...) you can't go around the world and just plant flags and say "we're claiming this territory"' (Current Digest of the Post-Soviet Press 2007). Against this background, the flag planting could be seen as a revisionist attempt to challenge 'the rules of the game' in the Arctic based on the UNCLOS. Nonetheless, classification of the flag planting as a revisionist challenge of the UNCLOS would seem to depend on the certain conditions. Given the operationalisation of a revisionist power as a power challenging the existing legal framework based on the UNCLOS, it seems possible to deduce the following minimum conditions. First, the flag planting expedition would have to reflect continuity with Russia's previous foreign policy in the Arctic. Second, the flag planting would need to have had an international direction to assert Russia's claims vis-à-vis the other Arctic coastal states. Third, high-level decision-makers in Russia would need to have welcomed the flag planting. What follows explores the extent to which the three conditions are satisfied.

\subsection{Policy continuity}

The origins of Arktika 2007 are somewhat obscure. Russia has previously organised similar expeditions known as Arktika 2000 and Arktika 2005 in order to collect scientific data and prove Russia's claims within the UNCLOS framework (Indzhiyev 2010: 37, ITAR-TASS 2005). The continuity between Arktika 2007 and Russia's previous foreign policy in the Arctic region has also been stressed by the Russian member of the UN Commission on the Limits of the Continental Shelf (CLCS), Yury Kazmin. According to Kazmin, 'the political significance of [the flag planting] can be hardly overestimated' since the flag planting 'confirmed that Russia has not abandoned its claim to the continental shelf and the resources of the seabed up to the North Pole (...) and that she shall never revise the limit once outlined' (Kazmin 2010: 27). The continuity between Arktika 2007 and Russia's previous foreign policy in the Arctic is, nonetheless, far from perfect. In fact, the idea of performing a manned descent to the seabed of the North Pole appears to have been conceived already in 1997 among a group of international explorers led by the Australian Mike McDowell. The original idea was to conduct the endeavour as a passengerfunded expedition using the Russian MIR deep-submergence vehicles, but it proved difficult to find enough passengers willing to pay for the project. For that reason, the 
plan did not develop further until the Swedish-German businessman Frederik Paulsen joined the project in 2005 and agreed to 'funding a significant proportion of the costs' in return for a place in one of the MIR submersibles (McDowell, Batson 2007: 8). Still, the organisers had difficulties securing icebreakers and the expedition did not get underway until the prominent Russian polar explorer and presidential Arctic representative, Artur Chilingarov, took over the organisation of the logistics and used his clout 'to fund the remaining cost of mounting the expedition' (McDowell, Batson 2007: 9). With the assistance of Chilingarov, who is also a deputy speaker of the Russian State Duma representing the dominant United Russia party, the expedition was authorised by the Russian government and approved by the Maritime Board under the Russian government. Formally, Arktika 2007 was organised by the Institute of Oceanography under the Russian Academy of Sciences. The Institute of Oceanography, in turn, delegated the task of carrying out the expedition to the non-commercial Russian Polar Research Foundation which is established by the Russian Association of Polar Explorers headed by Chilingarov. Interestingly, though, officials from the Institute of Oceanography are reported to have refused to comment on the financial sources of the expedition (Current Digest of the Post-Soviet Press 2007, ITAR-TASS 2007d, ITARTASS 2007c). All told, the unclear level of government involvement in the organisation and funding of Arktika 2007 suggests that the first condition of policy continuity is not satisfied.

\subsection{Policy Direction}

According to Chilingarov, the most important result of Arktika 2007 was that 'we showed that the Arctic is ours, the Russian Arctic (...) the Arctic has always been Russian and will always be Russian' (Moskovskiy komsomolets 2007). Chilingarov's words could suggest that the flag planting had an international direction and aimed to challenge the other Arctic coastal states. Chilingarov's statements concerning the purpose of the expedition are, however, not entirely consistent. In another interview, Chilingarov has simply called Arktika $2007^{\prime}$ a geographic expedition' whose main goal was the descent to the North Pole seabed (Moskovskiye novosti 2007). Moreover, Arktika 2007 incorporated a number of symbols relating to the dominant United Russia party which seem superfluous outside a Russian context. Apart from Chilingarov, United Russia was represented by another State Duma member, Vladimir Gruzdev, who was also onboard the MIR-1 when the Russian flag was placed on the North Pole seabed. The MIR-1 also left a time capsule on the seabed which contained a United Russia banner. The lead- ing United Russia member and head of the International Affairs Committee in the Russian Federation Council, Mikhail Margelov, publicly welcomed the capsule with the United Russia banner as 'an excellent PR move by his party colleagues' (Current Digest of the Post-Soviet Press 2007). The domestic direction of Arktika 2007 is also indicated by the fact that assertive Arctic endeavours have resonance among the Russian public according to opinion polls. More than 70 percent of the respondents in one poll, for example, had an 'encouraging attitude' towards Arktika 2007, while 90 percent had no doubts as to the legitimacy of a Russian claim to the North Pole (ITARTASS 2007a). The references to United Russia suggest a domestic purpose which is difficult to combine with the second condition of an international direction to assert Russia's claims vis-à-vis the other Arctic coastal states.

\subsection{High-level reactions}

Arktika 2007 might have developed outside the traditional channels of Russian foreign policy in the Arctic, but the Russian authorities quickly embraced the project once the descent to the North Pole seabed was successfully carried out (Current Digest of the Post-Soviet Press 2007). Then President Putin, for example, personally phoned the participants shortly after the descent to congratulate them (ITAR-TASS 2007c, ITAR-TASS 2007b). The praise from President Putin was seconded by similar statements from other prominent Russian officials like the speaker of the State Duma and leading member of United Russia, Boris Gryzlov (ITAR-TASS 2007e). Even the Russian Patriarch at the time, Aleksiy II, welcomed the descent, commenting that Arktika 2007 was a historic event which had 'enhanced Russia's prestige' (Kolodkin, Glandin 2007: 15). As another sign of high-level support, Chilingarov was invited for a private meeting at the presidential residence upon his return to Russia and was told that the expedition members had 'accomplished a great deed for our state' (Moscow News 2008). In January 2008, the high-level support was reiterated when President Putin signed a decree awarding the title Hero of the Russian Federation to the crew members of the MIR-1 'for the courage and heroism they showed under extreme conditions and the successfully conducted operation' (ITAR-TASS 2008a).

The enthusiastic official response to Arktika 2007 notwithstanding, however, high-level Russian officials have also been cautious not to link the flag planting to Russia's claims in the Arctic. At the meeting with Chilingarov at the presidential residence, for instance, President Putin explicitly stressed that the results obtained by Arktika 2007 should become the basis of Russia's stand during future discussions with the other Arctic coastal 
states. In the words of President Putin, 'the fact that the ranges are the continuation of the Russian shelf should be discussed with scientists (...) we should prove it at international organisations' (ITAR-TASS 2008a). Shortly after awarding the Hero of the Russian Federation titles to the MIR-1 crew members, President Putin also made it clear that Russia is collecting evidence in the Arctic precisely because Russia wants to ensure 'an open and objective dialogue' and that Russia will continue its work 'within the framework of existing international procedures' (Shaverdov 2008: 110). Similarly, the flag planting has been downplayed by the Russian Foreign Minister, Sergey Lavrov, who has compared the flag planting to the American flag on the Moon and argued that Arktika 2007 was part of 'the extensive work that is based on the Convention on the Law of the Sea' (Kolodkin, Glandin 2007: 15). During the Ilulissat Summit in May 2008, Foreign Minister Lavrov made the same point, explicitly denying that the flag planting signals a Russian claim to the North Pole. In Foreign Minister Lavrov's words, Russia does not 'and cannot have any claims to that territory (...) there is the UN Convention on the Law of the Sea and a mechanism of its fulfilment, which also concerns the issue of the continental shelf' (ITAR-TASS 2008b). The third condition is consequently only partially fulfilled since the enthusiastic high-level reactions are accompanied by reassurances of Russia's adherence to the UNCLOS.

Overall, the case study of the Russian flag planting challenges the explanatory power of the revisionist interpretation. Nonetheless, the disharmony between Chilingarov's forceful rhetoric and the official policy line advocated by the presidential administration and the foreign ministry suggests that the revisionist interpretation cannot be rejected entirely. For that reason, the second case study delves into the Ilulissat Summit in 2008 to test the status quo interpretation in further detail.

\section{The Ilulissat Summit}

In May 2008, the five Arctic coastal states gathered in the Greenlandic town of Ilulissat to discuss the future of the Arctic region. The two-day conference officially known as the Arctic Ocean Conference took place on 27-29 May 2008 and resulted in the Ilulissat Declaration which was widely seen as defusing the Arctic conflict potential. Explicitly mentioning the UNCLOS, the Ilulissat Declaration notes that 'an extensive international legal framework applies to the Arctic Ocean' and that the 'Arctic Five' remain 'committed to this legal framework and to the orderly settlement of any possible overlapping claims' (Ilulissat Declaration 2008). Against this background, Russia's participation at the Ilulissat Summit fits in well with the status quo interpretation. Even so, classification of Russia as a status quo power on the basis of the Ilulissat Summit would also seem to depend on certain basic conditions. Given the operationalisation of a status quo power as a power adhering to the existing legal framework based on the UNCLOS, the following minimum conditions can be deduced. First, a status quo interpretation would depend on evidence of a positive Russian engagement before the summit. Second, the findings would have to reveal a constructive Russian behaviour during the summit. Third, Russia would need to have communicated its participation domestically and internationally following the summit.

\subsection{Pre-summit Engagement}

The Ilulissat Summit was convened 'at the invitation of the Danish Minister for Foreign Affairs and the Premier of Greenland' (Ilulissat Declaration 2008). The summit emerged as a continuation of an informal brain-storming session among the 'Arctic Five' which Norway hosted in Oslo in October 2007 and the invitations for the Ilulissat Summit were issued only after informal consultations with Norway (Petersen 2008: 56). Russia, by contrast, was not directly involved in the preparations for the Ilulissat Summit, but has by and large supported the launch of 'Arctic Five' cooperation. In Oslo, for instance, Russia's representatives noted the applicability of an extensive international legal framework to the Arctic Ocean including the UNCLOS and emphasised Russia's commitment to continued cooperation in the Arctic (Norwegian Foreign Ministry 2007). Russia also acted in a cooperative way during the preparations for the Ilulissat Summit. In January 2008, for example, the Danish government presented the participating states with a discussion paper which noted the adequacy of the existing legal framework. Russia accepted the discussion paper and was particularly satisfied with an explicit reference to the UNCLOS (Petersen 2008: 59-61). Russia's cooperation during the initial preparations for the Ilulissat Summit was followed by a highly proactive engagement immediately before the summit. Notably, the Russian Foreign Minister Lavrov visited Copenhagen on his way to Greenland (Rossiyskaya gazeta 2008). According to a Russian newspaper, Foreign Minister Lavrov aimed to reassure his Danish colleague of Russia's cooperative attitude in advance, downplaying Russia's assertive moves in the Arctic and emphasising the importance of the UNCLOS (Vremia novostey 2008). On the whole, the evidence relating to Russia’s pre-summit engagement would therefore seem to fulfil the first condition. 


\subsection{Behaviour during the Summit}

The actual negotiations of the Ilulissat Summit took place on 28 May 2008. The first half of the day was devoted to less disputed matters like the effects of climate change and issues pertaining to indigenous peoples in the Arctic. Afterwards, the controversial issue of Arctic sovereignty was discussed during the second half of the day (Rossiyskaya gazeta 2008). The level of diplomatic representation constitutes an instructive starting point when examining Russia's behaviour during the summit. Russia has historically been very conscious about parity in the level of diplomatic representation in general and parity with the United States in particular. Russia's particular emphasis on the relationship with the United States is clearly reflected by the fact that Foreign Minister Lavrov held bilateral talks with the US Deputy Secretary of State, John Negroponte, on the sidelines of the summit (Russian Foreign Ministry 2008a). For these reasons, it is worth noting that Russia like Denmark and Norway was represented by its foreign minister, whereas Canada was represented by the Canadian Minister for Natural Resources and the United States was represented at the level of Deputy Secretary of State. While the absence of the Canadian Foreign Minister reflected his resignation on the eve of the summit, the lower level of American representation appears to have been a conscious choice. Russian observers, in any case, note that the representative of the United States was a less influential figure and the representation by a 'secondary figure' is seen as an indication that the United States did not attach great importance to the summit (Kommersant 2008, Usviatsov 2009: 4). The presence of Foreign Minister Lavrov at the summit despite the level of American representation suggests a constructive Russian behaviour insofar as Russia could have sent one of Russia's eight Deputy Foreign Ministers of whom one is primarily responsible for multilateral diplomacy and climate change related issues (Russian Foreign Ministry 2010). In that way, Russia could have given the impression of complying with the framework of international law and maintained diplomatic parity with the United States simultaneously.

The congruence between Russia's official position at the summit and the wording of the Ilulissat Declaration also indicates a constructive Russian behaviour. The minutes of the negotiations are not publicly accessible, but the Russian position is reflected by a speech which Foreign Minister Lavrov gave at the summit. In the speech, Foreign Minister Lavrov emphasised the common interests uniting the Arctic coastal states and avoided reference to extra-regional actors like Finland, Iceland, and Sweden which are also members of the Arctic Council, but do no border directly on the Arctic Ocean. Specifically,
Foreign Minister Lavrov made it clear that Russia did not share 'alarmist prognoses' of a future 'battle for the Arctic' (Lavrov 2008b). Instead, he explicitly stressed the importance of the UNCLOS and concluded by noting how the Arctic is becoming 'our common home', echoing Gorbachev's vision of a 'common European home' (Lavrov 2008b).

Russia's focus on the Arctic coastal states and the existing legal framework based on the UNCLOS is clearly reflected in the final wording of the Ilulissat Declaration. The declaration repeatedly refers to 'the five coastal states' and their special status in the Arctic and makes a clear distinction between the coastal states and 'other interested parties' (Ilulissat Declaration 2008). Moreover, in keeping with the Russian position, the Ilulissat Declaration emphasises the existing framework of international law and explicitly mentions the UNCLOS (Ilulissat Declaration 2008). The level of Russian representation and the congruence between Russia's official position and the final wording of the Ilulissat Declaration would seem to satisfy the second condition of a constructive Russian behaviour during the summit.

\subsection{Communication}

Immediately after the summit, Foreign Minister Lavrov spoke at a joint press conference with the other participants. At the conference, Foreign Minister Lavrov called the results of the summit 'substantial and useful' and added that the summit 'showed that we have common interests' (Lavrov 2008a). Notably, the Ilulissat Declaration was said to reflect the resolve of all the participants to solve all potential problems 'on the basis of international law' (Lavrov 2008a).

The day after the summit, the Russian Foreign Ministry issued a short press release on the results of the Arctic Ocean Conference. The press release mentioned the intent of expanding cooperation among the Arctic states and the commitment to legal solutions of any disputes (Russian Foreign Ministry 2008b). The press release was also published in English and French versions which were clearly addressed at an international audience. On the contrary, it has not been possible to identify evidence of similar domestic communication apart from the Russian version of the press release. Likewise, few domestic actors seem to have commented on Russia's participation at the summit.

Again, however, the presidential representative Artur Chilingarov stands out. After the summit, Chilingarov publicly refuted Foreign Minister Lavrov's remarks that Russia has no claims to the North Pole, saying that Foreign Minister Lavrov 'speaks as a diplomat' (Kommersant 2008). Chilingarov stated that Russia did not need to 
negotiate further but should simply continue working towards proving its claims. Moreover, Chilingarov warned against waiting until other countries arrive at the North Pole and urged that Russia should summon strength and 'do everything to see that Russia grows through the addition of the North Pole' (Kommersant 2008). The attempt to downplay the importance of the Ilulissat Summit is difficult to overlook considering Chilingarov's close links with the presidential administration and United Russia. The scarce and rather ambiguous communication of the Ilulissat Summit therefore provides little support for the status quo interpretation and suggests that internal disharmony remains a feature of Russian foreign policy in the Arctic.

Overall, though, the case study of Russia's participation at the Ilulissat Summit provides significant support for a status quo interpretation of Russian foreign policy in the Arctic.

\section{Conclusion}

Status quo and revisionist interpretations both capture important elements of Russian foreign policy in the Arctic. On the one hand, in keeping with the status quo interpretation, the case studies show that the UNCLOS enjoys considerable support within the presidential administration and the Russian foreign ministry which favour international cooperation in the Arctic. Recent events provide additional support for a status quo interpretation of Russian foreign policy in the Arctic. In March 2010, for instance, Russia confirmed the support for the existing legal framework at the 'Arctic Five' follow-up summit in Canada where the 'Arctic Five' reiterated their commitment to an orderly resolution of overlapping claims 'within the extensive international legal framework that applies to the Arctic Ocean' (Canadian Foreign Ministry 2010). The following month, Russia and Norway finally agreed to resolve a long-standing dispute over the maritime border in the Barents Sea (Trenin 2010: 10). Russia's adherence to the UNCLOS was once again demonstrated when the Akademik Fyodorov sailed off from St Petersburg in July 2010 to gather additional data to substantiate Russia's claims within the UNCLOS framework (ITAR-TASS 2010a). Most recently, Russian Prime Minister Putin told an international audience in Moscow in September 2010 that he had 'absolutely no doubt that the existing Arctic problems (...) could be solved in the spirit of partnership through negotiations and on the basis of the existing norms of international law' (Putin 2010).

On the other hand, the assertiveness emphasised by revisionist interpretations highlights the fact that Russia is not a unitary actor. The forceful rhetoric from Chilingarov demonstrates the existence of more assertive views on the Arctic which the Russian leadership sometimes seems to accommodate. Remarkably, even Chilingarov has recently moved to emphasise Russia's adherence to the UNCLOS following the commotion in connection with the flag planting (Moscow News 2008, ITAR-TASS 2010b). Chilingarov is, however, not the only proponent of an assertive Russian stance in the Arctic. Notably, the commander in chief of the Russian navy, Admiral Vladimir Vysotskiy, has warned that while there is presently peace and stability in the Arctic a power-based revision up to the point of armed intervention cannot be excluded in the future (Usviatsov 2009: 3). Noting an increase in the military activities of the NATO members in the Arctic, the secretary of the Russian Security Council and former director of the Federal Security Service (FSB), Nikolai Patrushev, has similarly urged that Russia should 'take action now' to prevent NATO members from driving Russia away from the Arctic (Zyśk 2009: 118).

A modified version of the status quo interpretation incorporating revisionist insights would therefore suggest that Russia is an Arctic status quo power seeking international cooperation despite some domestic support for an assertive stance which can explain the existence of revisionist interpretations.

\section{Bibliography}

Baev, PK 2010, 'Russian Policy in the Arctic: A Reality Check' in D Trenin \& PK Baev (eds.), The Arctic: A View from Moscow, Carnegie Endowment for International Peace, Moscow.

Borgerson, SG 2008, 'Arctic Meltdown. The Economic and Security Implications of Global Warming', Foreign Affairs, vol. 87, no. 2, pp. 63-77.

Canadian Foreign Ministry 2010, 29 March last update, Minister Cannon Highlights Canada's Arctic Leadership at Arctic Ocean Foreign Ministers' Meeting. Available: http://www.international.gc.ca/ media/aff/news-communiques/2010/120.aspx?lang=eng [2010, 10 October].

Cohen, A, Szaszdi, LF \& Dolbow, J 2008, 'The New Cold War: Reviving the U.S. Presence in the Arctic', The Heritage Foundation, Executive Summary, Backgrounder, No. 2022.

Colson, DA 2003, 'The delimitation of the outer continental shelf between neighboring states', American Journal of International Law, vol. 97, no. 1, pp. 91-107.

Current Digest of the Post-Soviet Press 2007, Cold War Goes North - Russia and West Begin Struggle for Arctic.

Eckstein, H 1975, 'Case Study and Theory in Political Science' in NW Polsby \& FI Greenstein (eds.) Handbook of Political Science. Volume 7: Strategies of Inquiry, Addison-Wesley Publishing Company, Massachusetts, pp. 79-137.

George, AL \& Bennett, A 2005, Case Studies and Theory Development in the Social Sciences, MIT Press, Cambridge, Mass.

Gerring, J 2007, Case Study Research: Principles and Practices, Cambridge University Press, New York. 
Gilpin, R 1981, War and Change in World Politics, Cambridge University Press, Cambridge.

Golotiuk, YV 2008, "На страже белого безмолвия (Na strazhe belogo bezmolviya/Guarding the White Silence)", Россия 6 глобальной политике (Rossiya v global'noy politike/Russia in Global Affairs), vol. 3.

Ilulissat Declaration 2008, 28 May last update, The Ilulissat Declaration. Arctic Ocean Conference. Ilulissat, Greenland, 27-29 May 2008. Available: http://www.oceanlaw.org/downloads/arctic/Ilulissat_Declaration.pdf [2010, 18 November].

Indzhiyev, A 2010, Битва за Арктику. Будет ли Север Русским? (The Battle for the Arctic. Will the North be Russian?), Ayзa (Yauza) \& Эксмо (Eksmo), Moscow.

ITAR-TASS 2010a, Scientists To Specify Russia's Continental Shelf Boundaries In Arctic.

ITAR-TASS 2010b, Уточнение границ континентального шельфа РФ продолжится в Арктике (Utochneniye granits kontinental'nogo shel'fa RF prodolzhitsya v Arktike/Delineation of the continental shelf of the Russian Federation will continue in the Arctic).

ITAR-TASS 2008a, Honorary titles, decorations conferred on polar explorers.

ITAR-TASS 2008b, Russian flag on Arctic seabed doesn't imply territorial claims.

ITAR-TASS 2007a, Most Russians believe defense of rights in Arctic grounded.

ITAR-TASS $2007 \mathrm{~b}$, Putin congratulates participants in North Pole expedition.

ITAR-TASS 2007c, Russia [sic] Arctic expedition is just 170 miles from North Pole.

ITAR-TASS 2007d, Russia [sic] Arctic expedition leaving $N$ Pole after successful dive.

ITAR-TASS 2007e, Russia's Duma speaker sends greetings to Russian Arctic expedition.

ITAR-TASS 2005, Russian Arctic fleet flagship reaches North Pole.

Johnston, AI 2003, 'Is China a Status Quo Power?', International Security, vol. 27, no. 4, pp. 5-56.

Kazmin, Y 2010, 'On the Issue of the Outer Limit of Russia's Arctic Continental Shelf', International Affairs: a Russian Journal of World Politics, Diplomacy and International Relations, vol. 56, no.3, pp. 8-30.

King, G, Verba, S \& Keohane, RE 1994, Designing Social Inquiry: Scientific Inference in Qualitative Research, Princeton Unversity Press, Princeton.

Kolodkin, A \& Glandin, S 2007, 'The Russian Flag on the North Pole', International Affairs: a Russian Journal of World Politics, Diplomacy and International Relations, vol. 53, no. 6, pp. 6-16.

Kommersant 2008, В узком полярном кругу (V uzkom poliarnom krugu/In a narrow Arctic circle).

Kunoy, B 2007, 'A New Arctic Conquest: The Arctic Outer Continental Margin', Nordic Journal of International Law, vol. 76, no. 4, pp. 465-480.

Lavrov, S 2008a, 29 May last update, Вступительное слово Министра иностранных дел России С.В.Лаврова на пресс-конференции по итогам министерскойпвстречи пяти прибрежных арктических государств, Илулиссат, Гренландия, 28 мая 2008 года (Vstupitel'noye slovo Ministra inostrannykh del Rossii S.V. Lavrova na press-konferentsii po itogam ministerskoy vstrechi piati pribrezhnykh arkticheskikh gosudarstv, Ilulissat, Grenlandiya, 28 maya 2008 goda/Opening address by Foreign Minister of Russia Sergey Lavrov at joint press conference on the results of the meeting of ministers from the five Arctic coastal states, Ilulissat, Greenland, 28 May 2008). Available: http://www.mid.ru/Brp_4.nsf/arh/
BDCEB5A105679F25C325745800347071?OpenDocument [2010, 10 October].

Lavrov, S 2008b, 29 May last update, Выступление Министра иностранных дел России С.В.Лаврова на конференции пяти прибрежных арктических государств, Илулиссат, Гренландия, 28 мая 2008 года (Vystupleniye Ministra inostrannykh del Rossii S.V. Lavrova na konferentsii piati pribrezhnykh arkticheskikh gosudarstv, Ilulissat, Grenlandiya, 28 maya 2008 goda/Speech by Foreign Minister of Russia Sergey Lavrov at the conference of the five Arctic coastal states, Ilulissat, Greenland, 28 May 2008). Available: http://www.mid.ru/Brp_4.nsf/arh/A8F5BBBDD03AF84DC32574 5800314235? OpenDocument [2010, 10 October].

Lucas, E 2009, The New Cold War: Putin's Russia and the Threat to the West, Palgrave Macmillan, New York.

McDowell, M \& Batson, P 2007, Last of the Firsts: Diving to the Real North Pole, The Explorers Club.

Morgenthau, HJ 1973, Politics among Nations. The Struggle for Power and Peace, Alfred A. Knopf, New York.

Moscow News 2008, Arthur Chilingarov: Russia's Arctic Explorer.

Moskovskiy komsomolets 2007, Артур Чилингаров: Мы доказали - Арктика наша (Artur Chilingarov: My dokazali - Arktika nashal Artur Chilingarov: We have proved that the Arctic is ours).

Moskovskiye novosti 2007, Артур Чилингаров: Мы сделали географическое открытие (Artur Chilingarov: My sdelali geograficheskoye otkrytiye/Artur Chilingarov: We have made a geographic discovery).

Norwegian Foreign Ministry 2007, 17 October-last update, The Arctic Ocean - meeting in Oslo, Press release, No.: 128/07, 17 October 2007. Available: http://www.regjeringen.no/en/dep/ ud/press/News/2007/The-Arctic-Ocean--meeting-in-Oslohtml?id=486239\&epslanguage $=$ en - GB [2010, October 9].

Petersen, N 2008, 'The Arctic as a New Arena for Danish Foreign Policy: The Ilulissat Initiative and its Implications' in Danish Foreign Policy Yearbook 2009, eds. N. Hvidt \& H. Mouritzen, Danish Institute of International Studies, Copenhagen, pp. 35-78.

Putin, V 2010, 23 September-last update, Председатель Правительства Российской Федерации В.В.Путин выступил на Международном форуме „Арктика - территория диалога" (Predsedatel' Pravitel'stva Rossiyskoy Federatsii V.V. Putin vystupil na Mezhdunarodnom forume "Arktika - territoriya dialoga“ Russian Prime Minister V.V.Putin spoke at the International Forum 'The Arctic - territory of dialogue'), 23 September 2010. Available: http://government.ru/docs/12304/print/ [2010, 9 October].

Rossiyskaya gazeta 2008, Лавров и Маргрете (Lavrov i Margrete) Lavrov and Margrethe).

Rowe, EW 2009, 'Introduction: Policy Aims and Political Realities in the Russian North' in EW Rowe (ed.) Russia and the North, University of Ottawa Press, Ottawa, pp. 1-15.

Russian Foreign Ministry2010, 10 October-last update, Заместители Министра иностранных дел Российской Федерации (Zamestiteli Ministra inostrannykh del Rossiyskoy Federatsii/Deputy Foreign Ministers of the Russian Federation). Available: http://www.mid.ru/ bul_newsite.nsf/kartaflat/03.02 [2010, 10 October].

Russian Foreign Ministry 2008a, 29 May-last update, Press Release: Russian Minister of Foreign Affairs Sergey Lavrov Meets with US Deputy Secretary of State John Negroponte. Available: http://www.mid. ru/Brp_4.nsf/arh/9C1B11A725DB4256C3257459002329C2?Open Document [2010, 10 October].

Russian Foreign Ministry 2008b, 29 May-last update, Сообщение для СМИ: Об участии Министра иностранных дел России С.В.Лаврова в конференции прибрежных арктических государств, Илулиссат, Гренландия, 28 мая 2008 года (Soobs- 
hcheniye glia SMI: Ob uchastii Ministra inostrannykh del Rossii S.V. Lavrova $v$ konferentsii pribrezhnykh arkticheskikh gosudarstv, Ilulissat, Grenlandiya, 28 maya 2008 goda/Press release: On the participation of Russia's Foreign Minister S.V. Lavrov at the conference of Arctic coastal states, Ilulissat, Greenland, 28 May 2008). Available: http://www. mid.ru/Brp_4.nsf/arh/157B406B6D52F1FFC3257458002E0D0F? OpenDocument [2010, 10 October].

Shaverdov, A 2008, „Арктика: лед и пламень (Arktika: lied i plamen'/The Arctic: ice and flame)“, Военный дипломат (Voеnпy diplomat/ Military Diplomat), vol. 2, pp. 110-119.

Trenin, D 2010, „The Arctic: A Front for Cooperation Not Conflict“ in The Arctic: A View from Moscow, eds. D. Trenin \& P.K. Baev, Carnegie Endowment for International Peace, Moscow.

Usviatsov, В 2009, „Кого согреет Арктика (Kogo sogreyet Arktika/ Who will be warmed by the Arctic)“, На страже Заполярья ( $\mathrm{Na}$ strazhe Zapoliaryal Guarding the Arctic), vol. 36.

Vremia novostey 2008, На айсберги не претендуем (Na aysbergi nе pretenduyem/We lay no claims to the icebergs).

Zyśk, K 2009, „Russia and the High North: Security and Defence Perspectives“ in SG Holtsmark \& BA Brooke (eds), Security prospects in the High North: geostrategic thaw or freeze, NATO Defence College, Research Division, Rome, pp. 102-129.

\section{Notes}

1. The UNCLOS specifies the conditions under which coastal states can claim an outer continental shelf beyond a 200-nautical-mile exclusive economic zone which is automatically stipulated in the UNCLOS (Colson 2003: 92-94, Kunoy 2007: 465-470). Russia ratified the UNCLOS in 1997 and became the first state to submit a claim within the UNCLOS framework for an outer continental shelf in the Arctic to the UN Commission on the Limits of the Continental Shelf (CLCS) in 2001. The CLCS rejected Russia's initial claim because of inadequate scientific evidence, but Russia has been gathering more data ever since in order to submit a new claim in 2013 or 2014 (Kazmin 2010: 27-28).

2. The word 'pravo' both means 'law' and 'right' in Russian. 